\title{
Leucopenia during paliperidone treatment in a patient with schizoaffective disorder - a case study
}

\author{
Leukopenia podczas leczenia paliperidonem u pacjentki
}

\section{z zaburzeniem schizoafektywnym - stadium przypadku}

\author{
1 Clinic of Psychiatry, Psychotherapy and Psychosomatics, Hospital Carl Thiem Klinikum in Cottbus, Cottbus, Germany \\ ${ }^{2}$ Department of Psychology, Kazimierz Wielki University in Bydgoszzz, Bydgoszzz, Poland \\ ${ }^{3}$ Endocrinology and Diabetology Practice, Gerhart-Hauptmann-Str.15, 03044 Cottbus, Cottbus, Germany \\ Correspondence: Bertrand Janota, Clinic of Psychiatry, Psychotheraphy and Psychosomatics, Carl Thiem Klinikum, Thiemstraße 111, 03048 Cottbus, tel.: +49 (0) 355 4678508, e-mail: janotabertrand@gmail.com
}

\author{
${ }^{1}$ Klinika Psychiatrii, Psychoterapii i Psychosomatyki, Carl Thiem Klinikum w Cottbus, Cottbus, Niemcy \\ ${ }^{2}$ Wydział Psychologii, Uniwersytet Kazimierza Wielkiego w Bydgoszczy, Bydgoszzz, Polska \\ ${ }_{3}^{3}$ Praktyka Lekarska Endokrynologia i Diabetologia, Gerhart-Hauptmann-Str. 15, 03044 Cottbus, Cottbus, Niemcy \\ Adres do korespondencij: Bertrand Janota, Klinika Psychiatrii, Psychoterapii i Psychosomatyki, Carl Thiem Klinikum, Thiemstraße 111, 03048 Cottbus, tel.: +49 (0) 3554678508 , \\ e-mail: janotabertrand@gmail.com
}

Abstract The case study presents a 51-year-old woman diagnosed with a schizoaffective disorder who was initially treated with risperidone. After 7 days of hospitalisation, the patient was discharged at her own request. On the same day, after a few hours, she returned to the emergency room, reporting severe anxiety and auditory hallucinations. Risperidone was replaced by paliperidone. During the treatment, a decrease in leucocyte count after paliperidone administration was observed. During further hospital stay, the treatment was switched to olanzapine in depot form. Correct symptomatic response to the drug used was observed. The leucocyte counts were gradually compensated, which confirms the drug-related cause of previously observed complete blood count abnormalities. The case indicates the possibility of side effects in the treatment with certain drugs, and underlines the impact of the dosage form of the drug being taken on the patient's quality of life.

Keywords: leucopenia, schizoaffective disorder, paliperidone, depot, drug side effect

Streszczenie W artykule przedstawiono studium przypadku 51-letniej kobiety, która była leczona z powodu zaburzenia schizoafektywnego początkowo risperidonem. Po 7 dniach hospitalizacji pacjentka została wypisana na własną prośbę. Tego samego dnia po kilku godzinach sama wróciła na izbę przyjęć, zgłaszając silny niepokój i halucynacje słuchowe. Risperidon zastąpiono paliperidonem. Podczas leczenia zaobserwowano spadek stężenia leukocytów po podaniu paliperidonu. Podczas dalszego pobytu lek zmieniono na olanzapinę w postaci depot. Potwierdzono poprawną symptomatyczną odpowiedź na zastosowany lek. Stężenia leukocytów stopniowo zostały skompensowane, co potwierdza związaną z lekiem przyczynę wcześniej zaobserwowanych zaburzeń w morfologii krwi. Opisany przypadek pacjentki ma znaczenie kliniczne, ponieważ wskazuje na możliwość występowania działań niepożądanych przy stosowaniu niektórych leków w leczeniu zaburzeń schizoafektywnych oraz zwraca uwagę na oddziaływanie formy przyjmowanego leku na jakość życia pacjenta.

Słowa kluczowe: leukopenia, zaburzenie schizoafektywne, paliperidon, depot, działanie niepożądane leku 


\section{INTRODUCTION}

$\mathrm{N}$ ew medicine groups and their application methods, coupled with a more selective profile of action in relation to different symptoms, have made psychopharmacotherapy more suited to the needs of patients suffering from schizoaffective disorders (e.g. Gründer et al., 2016). A particularly important group are antipsychotic medicines administered in the form of intramuscular injections with a prolonged action - the so-called depot medicines (Barrio et al., 2013; Kisely et al., 2015; Morris and Tarpada, 2017). This form of drug administration is recommended mainly for patients who fail to adhere to doctor's recommendations, young people with active lifestyles. The main advantages of depot medications are their low frequency of administration (from 2 weeks to 3 months) and constant concentration of the drug in the blood. Treatment with depot injections should be introduced gradually, starting with analogous medicines in the form of tablets. In the absence of side effects, the next step is to switch to the depot drug. In the case of paliperidone, at the beginning of the therapy, one should start with a dose adjustment of risperidone (e.g. Schreiner et al., 2015). The lowest effective dose of the drug is converted to the equivalent of paliperidone in depot form. The reported case draws attention to the possibility of leucopenia during paliperidone treatment, and underlines the impact of the form of the drug being taken on the quality of life of patients with schizoaffective disorders (see Kim et al., 2011; Taylor et al., 2018).

\section{ANAMNESIS}

We present a case of a patient diagnosed with a schizoaffective disorder. The most important data from her medical history are the following: a white woman, 51 years old, divorced, living alone, with completed higher education, a disability pensioner for 11 years because of her psychiatric disorder. She has two adult daughters with whom she has occasional contact. For several months she has been working in a kindergarten, where she is employed in the form of a mini job. The patient remains active during periods of remission. She has a group of regular friends with whom she spends time going to the cinema and theatre. She is interested in travel and literature. According to the patient, the disease has made her more withdrawn from social life, and sad.

She had been receiving psychiatric treatment since 2005 after being diagnosed with psychotic disorders. Initially, due to increased anxiety, fear, persecutory delusions, delusions of poisoning and secondary depressed mood, she was treated with risperidone (the maximum daily dose was $4 \mathrm{mg}$ ), and olanzapine was added to the treatment regimen in increasing doses due to insufficient drug efficacy. The patient took her medicines irregularly, and she did not report for follow-up visits. She often discontinued prescribed medi- "wanted to be like other healthy people." She had the impression that the pills dominated her life because she had to remember to take the prescribed drugs at the right time. After a few months, she had her first stationary treatment in the psychiatric ward.

\section{DESCRIPTION OF THE COURSE OF TREATMENT}

After 7 days of hospitalisation, the patient was discharged despite medical advice, at her own request. In the absence of indications for treatment against her will, she was discharged with the diagnosis of delusional disorders (F22.0), and the recommendation to take ziprasidone $60 \mathrm{mg}$ and olanzapine $10 \mathrm{mg}$ per day. However, on the day of discharge, after a few hours, the patient returned to the emergency room reporting severe anxiety and auditory hallucinations of imperative and commenting nature. During hospitalisation, due to the patient's lack of adherence to the therapeutic recommendations, it was decided to change the form of treatment from tablets to intramuscular injections with prolonged action (depot form). Due to the features of depressed mood, it was additionally decided to start antidepressant treatment. After 33 days of stationary hospitalisation with pharmacological treatment and therapy, the patient was discharged in a state of improvement for continued outpatient treatment. The recommendations included further systematic injections of depot paliperidone $75 \mathrm{mg}$ intramuscularly every 4 weeks, and the antidepressant citalopram $20 \mathrm{mg}$ once a day. Another stationary hospitalisation took place 30 days after the previous discharge. The patient reported to hospital with increased anxiety, low mood, and poisoning and persecutory delusions. The reason for the deterioration in the patient's condition was the fact that she had stopped taking the recommended medications. The ward again ordered to continue paliperidone treatment at the previous dose $(75 \mathrm{mg}$, intramuscular injections every 4 weeks).

In the course of further hospitalisation, a significant and increasing leucopenia was observed (see Fig. 1). A gradual decrease in leucocyte count from $6.4 \mathrm{Gpt} / \mathrm{L} \rightarrow 2.1 \mathrm{Gpt} / \mathrm{L}$

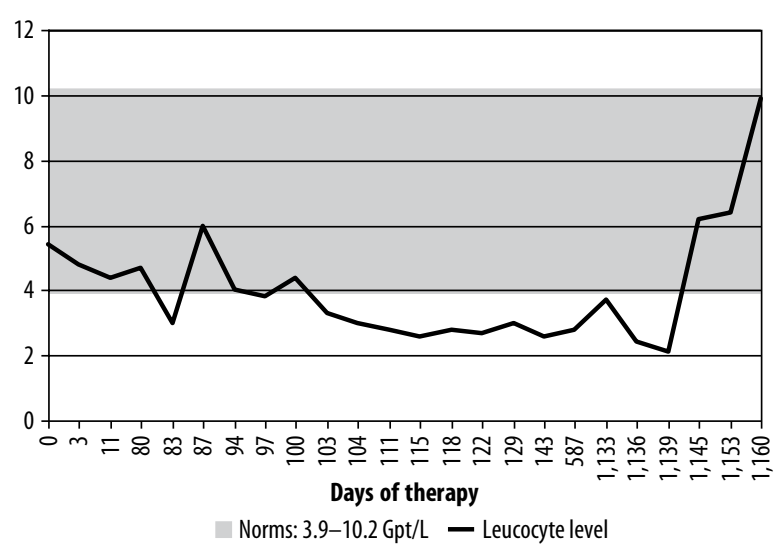

Fig. 1. Leucocyte level over consecutive days of treatment 
in the range of 3.9 to 10.2 standards was noted. Due to the suspicion of a proliferative disease, haematological and oncological consultations were held. During further hospitalisation, the patient's mental condition improved gradually. Her mood was stabilised, she used free trips to the house, and after discharge, further stabilisation in the day ward was planned. She was very keen to continue paliperidone treatment in the form of depot because of her personal circumstances.

Haematological and oncological consultations did not show any other abnormalities in the patient's blood count, except for leucopenia. In the course of further treatment, it was observed that the leucocyte count decreased significantly shortly after the administration of a depot injection. The above observations prompted the treatment team after talking to the patient to change the therapy. Paliperidone in the form of depot was discontinued, and olanzapine treatment in the form of depot was implemented. During further follow-up, both the stationary and daily ward confirmed the patient's good response to the prescribed drug. The psychological condition of the patient was completely balanced. In the course of further treatment, we also observed the levelling of leucocyte counts, which clearly proves the drugrelated cause of the initially observed leucopenia.

\section{CONCLUSIONS}

In the course of treatment for psychotic disorders, antipsychotic drugs with a prolonged duration of action are an important alternative, and sometimes the only possibility to treat psychotic conditions, as opposed to classical dosage forms. However, like all medicines, they also have side effects. Due to the half-life of depot drug activity in the blood, appropriate patient classification is crucial for this medication type, and close follow-up in the course of treatment is essential as well. For the physician and the patient, what counts is not only an improvement in the range of treated symptoms and absence of symptomatic adverse reactions, but also the lack of undesired treatment effects.

The case reported in the article has clinical significance for three reasons. First of all, it draws attention to the possibility of leucopenia as an undesirable effect of treatment of a schizoaffective disorder which in turn contributed to changing the therapeutic approach and adapting it to the emerging contraindications.

Secondly, an important question appears to be the lack of leucopenia in the course of risperidone treatment and its presence during therapy with the active metabolite (9-hydroxyrisperidone) - paliperidone. The explanation for this phenomenon may be the relatively short period of administration of risperidone (oral dosage form), different chemical structure of the metabolite, and thus different bioavailability, pharmacokinetics, and hence side effects. Perhaps the excipients contained in the formulation and necessary for its administration to achieve a prolonged effect also play a role here (Jarema et al., 2017).

Thirdly, the findings indicate the importance of the form of drug administration for the patient's quality of life and motivation to continue therapy. For the patient concerned, the drug in the form of depot formulation turned out to be a more convenient option because, in her opinion, it did not require constant monitoring of treatment. Importantly, the patient's subjective assessment of her life was more like "normal" functioning. This encouraged her to adhere to the treatment she had previously neglected for no apparent reason.

\section{Conflict of interest}

The authors do not report any financial or personal affiliations to persons or organisations that could negatively affect the content of or claim to have rights to this publication.

\section{References}

Barrio P, Batalla A, Castellví P et al.: Effectiveness of long-acting injectable risperidone versus oral antipsychotics in the treatment of recent-onset schizophrenia: a case-control study. Int Clin Psychopharmacol 2013; 28: 164-170.

Gründer G, Heinze M, Cordes J et al.: Effects of first-generation antipsychotics versus second-generation antipsychotics on quality of life in schizophrenia: a double-blind, randomised study. Lancet Psychiatry 2016; 3: 717-729.

Jarema M, Bieńkowski P, Heitzman J et al.: Paliperidone palmitate: effectiveness, safety, and the use for treatment of schizophrenia. Psychiatr Pol 2017; 51: 7-21.

Kim JN, Lee BC, Choi IG et al.: Paliperidone-induced leukopenia and neutropenia: a case report. Prog Neuropsychopharmacol Biol Psychiatry 2011; 35: 284-285.

Kisely S, Sawyer E, Robinson G et al.: A systematic review and metaanalysis of the effect of depot antipsychotic frequency on compliance and outcome. Schizophr Res 2015; 166: 178-186.

Morris MT, Tarpada SP: Long-acting injectable paliperidone palmitate: a review of efficacy and safety. Psychopharmacol Bull 2017; 47: 42-52.

Schreiner A, Aadamsoo K, Altamura AC et al.: Paliperidone palmitate versus oral antipsychotics in recently diagnosed schizophrenia. Schizophr Res 2015; 169: 393-399.

Taylor DM, Velaga S, Werneke U: Reducing the stigma of long acting injectable antipsychotics - current concepts and future developments. Nord J Psychiatry 2018; 72 (Supl 1): S36-S39. 